\title{
Phytopathology
}

\section{Plant Virus Metagenomics: Advances in Virus Discovery}

\author{
Marilyn J. Roossinck, Darren P. Martin, and Philippe Roumagnac
}

First author: Department of Plant Pathology and Environmental Microbiology, Center for Infectious Disease Dynamics, Pennsylvania State University, University Park, PA 16802; second author: Computational Biology Group, Institute of Infectious Diseases and Molecular Medicine, University of Cape Town, Cape Town, 7925 South Africa; and third author: CIRAD, UMR BGPI, Campus International de MontferrierBaillarguet, 34398 Montpellier Cedex-5, France.

Accepted for publication 19 February 2015

\begin{abstract}
Roossinck, M. J., Martin, D. P., and Roumagnac, P. 2015. Plant virus metagenomics: Advances in virus discovery. Phytopathology 105:716-727.

In recent years plant viruses have been detected from many environments, including domestic and wild plants and interfaces between these systems - aquatic sources, feces of various animals, and insects. A variety of methods have been employed to study plant virus biodiversity, including enrichment for virus-like particles or virus-specific RNA or DNA, or the extraction of total nucleic acids, followed by next-generation deep sequencing and bioinformatic analyses. All of the methods have some shortcomings, but taken together these studies reveal our surprising lack of knowledge about plant viruses and point to the need for more comprehensive studies. In addition, many new viruses have been discovered, with most virus infections in wild plants appearing asymptomatic, suggesting that virus disease may be a byproduct of domestication. For plant pathologists these studies are providing useful tools to detect viruses, and perhaps to predict future problems that could threaten cultivated plants.
\end{abstract}

Metagenomics is the analysis of microbial communities in environmental samples through sequencing. For prokaryotic or eukaryotic microbes universal sequences (usually ribosomal RNA regions) frequently are used (Riesenfeld et al. 2004), although more recently such studies include randomly primed sequence data in attempts to obtain whole genome information (Sharpton 2014). This results in a relatively unbiased assessment of the extremely diverse array of cell-based microbes. For viruses there are no universal genes or sequences, so viral metagenomic studies must utilize methods that are not sequence-specific. Various methods have been used to enhance the viral sequences in collected samples, followed by sequence analysis, either directly or after an amplification step. These viral metagenomic studies show that we have barely even begun to appreciate the immense diversity of viruses that occur on our planet (Stobbe and Roossinck 2014). In addition to identifying many novel viruses, 60 to $95 \%$ of sequences found in these studies have no detectable homologs in GenBank at all (Roossinck 2012b).

Many viral metagenomic studies have used environmental samples, but for plant viruses individual plants also have been used (Roossinck et al. 2010). While most viruses discovered in wild plants cannot be linked to any pathology, some of these viruses can be pathogenic when infecting domesticated plants. For plant

Corresponding author: M. J. Roossinck; E-mail address: mjr25@psu.edu

http://dx.doi.org/10.1094/PHYTO-12-14-0356-RVW

(C) 2015 The American Phytopathological Society pathologists the use of metagenomic data has many practical applications, including identification of potential pathogens for better food security (MacDiarmid et al. 2013) and advanced knowledge of viruses that could pose threats should they jump species into domestic plants.

In this review, we first retrace the history of virus metagenomics, highlighting the conceptual and technical achievements that have had the greatest impact on the present state of the field. We then focus specifically on the use and application of plant viral metagenomic approaches that have been developed over the last decade, and how these are relevant to plant pathology.

\section{A BRIEF HISTORY OF THE FIELD}

The term "metagenomics" first appeared in a 1998 article written by Jo Handelsman and coworkers (Handelsman et al. 1998), but the roots of the field can be traced back to the work of Norman Pace and colleagues in the 1980s and early 1990s (Pace et al. 1985; Schmidt et al. 1991). Through their seminal work on ribosomal RNA sampled directly from natural environments, Pace and coworkers revealed for the first time that the number of microbial species that could be cultured from such environments were a dramatically small fraction of all the microbial species found within these environments (Handelsman 2004).

Viruses in the sea were first assessed by electron microscopy 25 years ago, with estimates of about $10^{7}$ virus particles per ml of seawater, but these studies did not identify viruses beyond morphological 
characteristics (Bergh et al. 1989; Proctor and Fuhrman 1990; Suttle 2005). The sequence-based metagenomic concepts and techniques first used by fungal and microbial ecologists have progressively spread into the fields of virus ecology and pathology. The adoption of this approach by virologists was initially hindered by the fact that there are no virus genes that are universally conserved. The plausibility of viral metagenomics became apparent in 2001 when a pioneering study successfully used a DNase-sequence-independent single primer amplification method to discover new viruses (Allander et al. 2001). The power of viral metagenomics was revealed shortly thereafter when another seminal study used a shotgun cloning-based method to sequence uncultured aquatic viral communities (Breitbart et al. 2002). Since then more than 800 viral metagenomic studies have been published with continual improvements in next-generation sequencing (NGS) techniques enabling increasingly ambitious projects.

Just as ecologists have traditionally sampled fractions of an ecosystem ranging from entire biomes at scales of hundreds of kilometers to individual plots at a scale of meters (Tseng and Tang 2014), metagenomic studies of virus ecosystems have sampled at scales ranging from global ocean biomes (Rusch et al. 2007) to individual virus infected tissues ( $\mathrm{Ng}$ et al. 2009; Roossinck et al. 2010).

A key aspect of plant virus metagenomic studies that differentiates these from similar animal or microbial studies is that plants are immobile and can be repeatedly resampled. This means that plant viruses that are identified during a discovery phase not only can be traced back to specific geographical locations, but can also be further characterized within their original host at a future date. Plant virus metagenomic studies that capitalize on this potential have been termed ecogenomics to distinguish them from those using environmental samples (Fig. 1A) (Roossinck et al. 2010).

In order to enable the low-cost sequencing of pooled samples from multiple host plants in individual NGS runs, ecogenomics approaches have generally employed primer tagging strategies in which each geo-referenced host plant corresponds to one particular primer sequence tag (Fig. 1A). Based on these tags, individual NGS reads can be later traced back to specific host plants (Bernardo et al. 2013; Candresse et al. 2014; Roossinck et al. 2010; Wylie et al. 2013b).

\section{METHODS OF DATA ACOUISITION}

Plant viral metagenomic approaches have targeted four main classes of nucleic acids: (i) total RNA or DNA, (ii) virion-associated nucleic acids (VANA) purified from virus-like particles, (iii) double-stranded RNAs (dsRNA), and (iv) virus-derived small interfering RNAs (siRNAs) (Fig. 1B and Table 1). In addition, datamining of transcriptome and genome databases has been used for virus discovery.

Total RNA or total DNA. The simplest approach to viral metagenomics is to directly use total RNA or DNA extracted from plants. RNA/DNA extraction, sequence-independent amplification, and NGS have been used to reveal plant viral biodiversity both within individual plants and within pooled RNA samples from multiple plants to discover new virus species (Table 2, references within table), and the probable causal agents of viral diseases (Adams et al. 2013a, 2014b; Rwahnih et al. 2009).

The primary shortcoming of the total RNA/DNA approach is that a very high proportion of the sequence reads that are eventually obtained are not virus derived. If the number of reads per plant is low due to either inefficient sequencing or high degrees of multiplexing, viruses that occur at low titers may not be detected at all. Viruses with dsRNA genomes may also be missed as standard methods for reverse transcription reactions do not reliably copy dsRNA, and only single-stranded (ss)RNA transcripts would be detected.
One modification that has been used to increase the proportion of total reads that are virus derived has been subtractive hybridization (Adams et al. 2009; Monger et al. 2010). This involves selectively enriching for virus sequences by using immobilized RNA from a healthy plant to remove (or subtract) host-derived cDNA synthesized from an infected plant (Adams et al. 2009). This method may be appropriate for discovery of causal agents of disease, but it would not detect the persistent plant viruses that are the most common viruses found in wild plants (Roossinck 2012b), and are in many crop plants (Roossinck 2015), or other asymptomatic viruses that might be in the "healthy" plant.

Total DNA-based metagenomic approaches are also fairly straightforward for the detection and characterization of entirely novel DNA virus communities that are associated with various eukaryotic species or environments, including plants (Dayaram et al. 2012; S. Kraberger, K. Farkas, P. Bernardo, C. Booker, G. R. ArgüelloAstorga, F. Mesléard, D. P. Martin, P. Roumagnac, and A. Varsani, unpublished data). These approaches are particularly applicable to the discovery of DNA viruses with circular genomes since a sequence-independent rolling circle amplification step following DNA extraction can substantially increase the proportions of virusderived reads that are ultimately obtained.

VANA purified from viral particles. Metagenomics approaches based on the enrichment of virus-like particles (VLPs) have proven effective in the discovery of novel RNA and DNA viruses within animal and human tissue samples (Allander et al. 2001; Breitbart and Rohwer 2005; Jones et al. 2005). The principle of this approach is the effective removal of host nucleic acids so as to maximize the proportions of virus sequence reads obtained from NGS runs. Generally, up to four steps are used to achieve this: (i) VLP isolation using $\mathrm{CsCl}$ gradient or filtration-based techniques; (ii) RNAse and DNAse treatments to remove nonencapsidated nucleic acids; (iii) ultracentrifugation to harvest any virions present in the sample; and (iv) extraction of VANA that are protected within capsids (Hall et al. 2014). One advantage of this approach is that it initially combines reverse-transcriptase priming and a Klenow fragment polymerization step that can enable the simultaneous detection of both RNA and DNA viruses (Candresse et al. 2014).

The first evidence that VANA-based metagenomicsmethods might be applicable to the study of plant virus metagenomics came from an analysis of RNA viruses present within human fecal samples (Zhang et al. 2006). Although the primary objective of this study was the identification of human viruses, the most abundant fecal virus (up to $10^{9}$ virions per gram of dry weight fecal matter) was closely related to Pepper mild mottle virus (PMMV; family Virgaviridae, genus Tobamovirus). This study showed that PMMV shed from the human gastrointestinal tract was still infectious to Hungarian wax pepper (Capsicum annuum) plants (Zhang et al. 2006). Besides PMMV, other plant virus-related sequences related to Oat blue dwarf virus (family Tymoviridae, genus Marafivirus), Grapevine asteroid mosaic-associated virus (family Tymoviridae, genus Marafivirus), Maize chlorotic mottle virus (family Tombusviridae, genus Machlomovirus), Oat chlorotic stunt virus (family Tombusviridae, genus Avenavirus), Panicum mosaic virus (family Tombusviridae, genus Panicovirus), and Tobacco mosaic virus (family Virgaviridae, genus Tobamovirus) (Zhang et al. 2006) were also found. Unlike PPMV, it is unknown whether these other viruses were still viable. However, this and other similar environmental metagenomic studies that have recovered plant viruses (reviewed in Roossinck 2012b) unequivocally demonstrated the applicability of VANA-based metagenomics to plant virology.

In 2005, the Plant Virus Biodiversity and Ecology Project was set up to investigate the plant virus biodiversity of particular managed and unmanaged ecosystems using metagenomic strategies (Wren et al. 2006). This project arose from a much earlier effort to begin to 

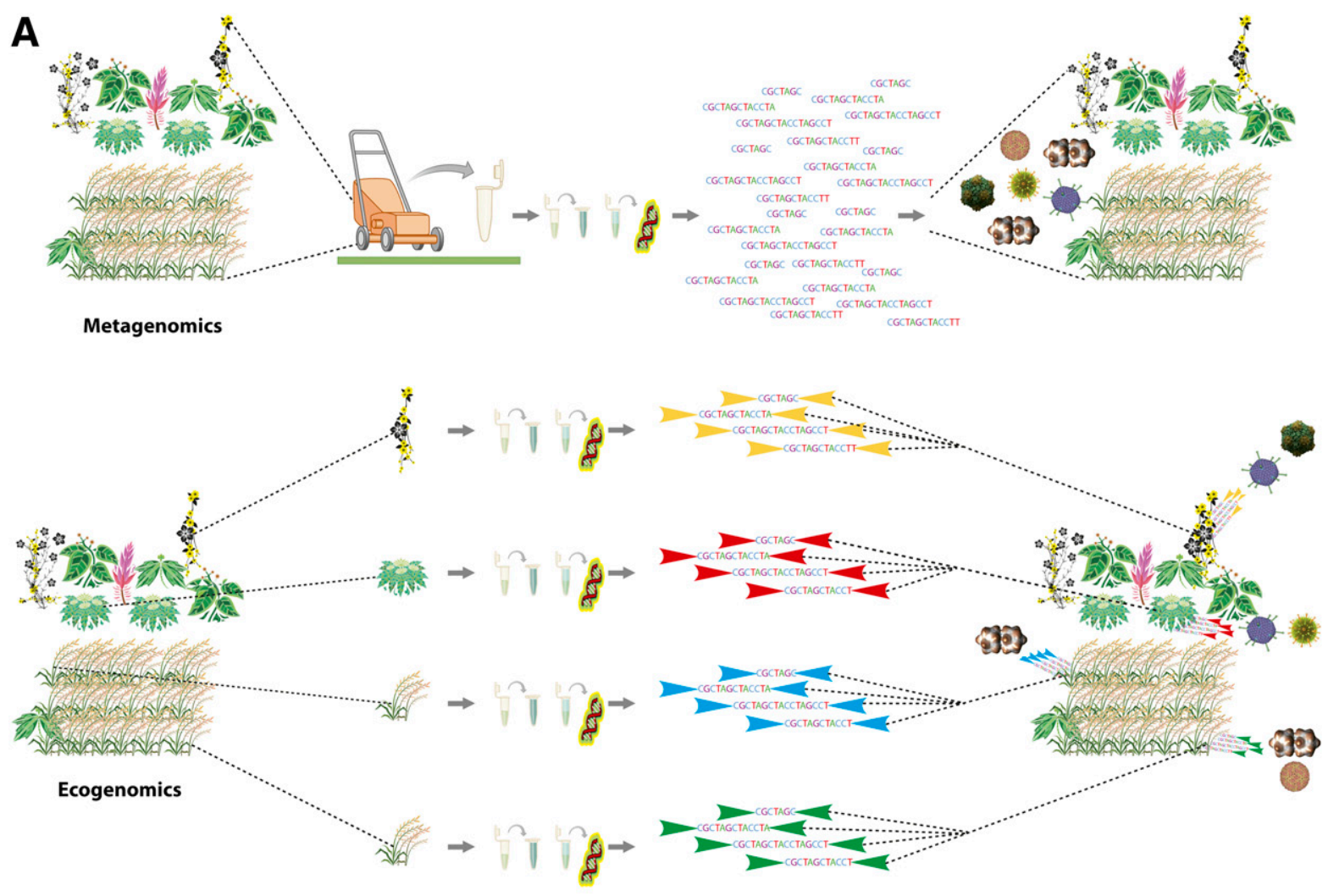

B

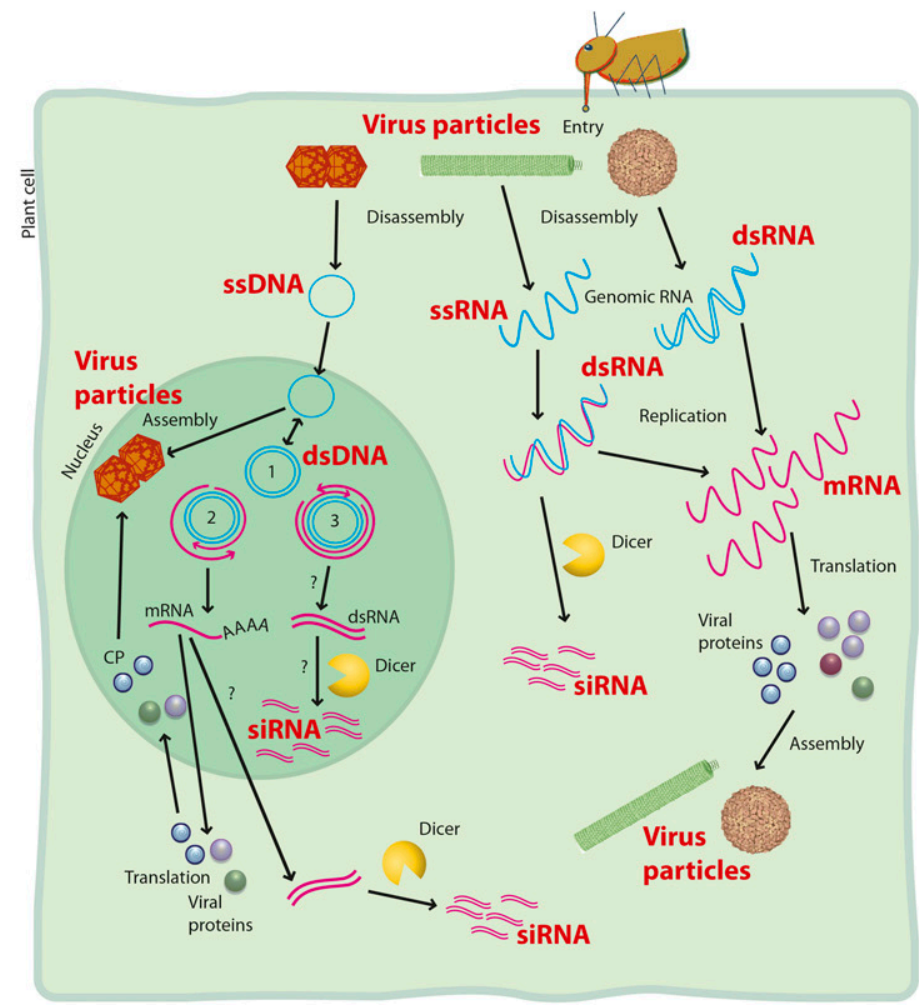

\section{FIGURE 1}

A, Schematic drawing of the processes used for metagenomics and ecogenomics. Sampling can be done by collecting an entire environmental sample (the "lawnmower" method; metagenomics) or by sampling individual plants (ecogenomics). Samples are processed for various types of nucleic acids, as described in the text. For metagenomic studies, nucleic acids are amplified using random primers followed by deep sequence analysis. For ecogenomic studies, specific tags are added to the random primers, and one tag is used for each sample. This allows multiplexing, the mixing of many samples for one deep sequencing run. The tags allow each sequence to be traced back to the original plant. B, Cartoon representation of a plant cell indicating various compartments where virus-associated nucleic acids are found. 
inventory all viruses in a diverse ecosystem as a part of an "All Taxa Biodiversity Inventory" of a biodiversity hotspot in northwestern Costa Rica. The Plant Virus Biodiversity and Ecology study used both VLP enrichment and dsRNA enrichment (see below). For this project the Tallgrass Prairie Preserve of northeastern Oklahoma, which contains about 700 species of plants, was initially chosen as a pilot sampling area. VLPs were enriched from individual plants by differential centrifugation and VANA were amplified by polymerase chain reaction (PCR) or reversetranscription (RT)-PCR (Melcher et al. 2008). Four other largescale VANA-based ecogenomic studies were conducted in 2010 and 2012 in the species rich Camargue and Western Cape regions of France and South Africa, respectively. The sampling locations targeted in these regions involved an agroecosystem, containing both natural (i.e., unmanaged or uncultivated) areas neighboring cultivated (i.e., managed) areas. Collectively the American, French, and South African large-scale VANA-based metagenomic studies revealed the presence of virus-related sequences in 25 to $58 \%$ of analyzed samples, the vast majority of which displayed no evidence of disease symptoms (Bernardo 2014).

These studies also indicated that the number of currently classified plant virus species is dramatically underestimated and biased: underestimated, because among the virus-derived sequences identified in South Africa in 2010, only $10 \%$ clearly belong to known virus species (using an arbitrary species demarcation threshold of $75 \%$ pairwise nucleotide sequence identity; Bernardo et al. 2014); biased, because most of the known plant virus species have been characterized from domesticated plants that comprise only a tiny fraction of all plant species currently living in natural ecosystems.

Besides providing the first estimation of the plant community prevalence of viruses at the agroecosystem scale, these studies have also discovered many interesting new viruses (Scheets et al. 2011; Thapa et al. 2012), some of which were subsequently further characterized using more traditional plant virology methods (Table 2, references within the table).

The main shortcomings of this approach are that it remains cumbersome, it may not detect unencapsidated viruses or those with unstable particles, and this approach cannot effectively recover viruses from plants having high levels of either phenolic compounds or highly viscous polysaccharides.
dsRNA. Virologists recognized long ago that RNA viruses often formed dsRNA either as their encapsidated genome or during the process of replication. This form of nucleic acids is largely unique to viruses, although small dsRNAs are found abundantly in plants, and folded structures in longer RNAs result in partially dsRNA molecules.

For dsRNA analyses nucleic acids are first purified through a phenol:chloroform extraction and the resulting mix of total DNA and RNA is enriched for dsRNA either by $\mathrm{LiCl}$ fractionation (Diaz-Ruiz and Kaper 1978) or the use of long polymer cellulose chromatography (Dodds et al. 1984).

For metagenomic studies of plant viruses, the use of dsRNA has provided a very in-depth analysis of virus-specific sequences (Roossinck 2012b;Roossinck et al. 2010). In general it has enabled the discovery of many new viruses, and has shown that in uncultivated plants studied so far, persistent viruses (predominantly those in the families Chrysoviridae, Endornaviridae, Partitiviridae, and Totiviridae) are the dominant types of plant viruses, even though very few species within these families have currently been recognized by the International Committee for the Taxonomy of Viruses (Roossinck 2012b). The use of dsRNA-based approaches has also been the predominant method for the discovery of fungal viruses (Roossinck 2014).

The main shortcomings of this approach are that it is labor intensive, it is not very effective for the detection of (-) sense ssRNA viruses (since these do not accumulate large amounts of dsRNA during replication), and it cannot be used for the detection of DNA viruses.

siRNA. The antiviral adaptive immune system of plants is a component of a more general sequence-dependent system for controlling gene expression that is known as RNA silencing. Whenever dsRNA occurs within a plant cell, such as occurs during the replication of RNA viruses, it is processed by Dicer-like proteins into 21- to 24-nucleotide siRNAs.

In 2009, two studies definitively demonstrated that virus-derived siRNAs could be used to detect both known and previously uncharacterized plant viruses within infected plants (Donaire et al. 2009; Kreuze et al. 2009). Since then, this approach has been extensively used to detect a variety of plant-infecting viruses (Table 2; references in the Table). Curiously, it has even been possible to reconstruct the genomes of DNA viruses such as caulimoviruses and geminiviruses (Hagen et al. 2011; Kreuze et al.

TABLE 1

Types of viral nucleic acids used for metagenomic studies

\begin{tabular}{|c|c|c|c|}
\hline $\begin{array}{l}\text { Virus- } \\
\text { associated } \\
\text { nucleic acida }\end{array}$ & Subcellular location & Virus genome types & Drawbacks \\
\hline dsRNA & Cytoplasm, virions & (+) ssRNA ${ }^{\mathrm{b}}$, dsRNA & Misses (-) RNA viruses and DNA viruses \\
\hline ssRNA & Cytoplasm, nucleus, virions & $\begin{array}{l}(+) \text { and (-) ssRNA; dsRNA } \\
\text { (as transcripts); DNA (as transcripts) }\end{array}$ & $\begin{array}{l}\text { High background; may miss low titer viruses; } \\
\text { may miss dsRNA genomes }\end{array}$ \\
\hline VANA & Cytoplasm, nucleus & ssRNA, dsRNA, ssDNA, dsDNA & $\begin{array}{l}\text { Cannot detect unencapsidated viruses such as } \\
\text { members of the family Endornaviridae; poor } \\
\text { recovery of viruses from some plants }\end{array}$ \\
\hline In silico & Databases of ESTs, MySeq & Those with poly-A tails & $\begin{array}{l}\text { Misses a majority of plant viruses; cannot } \\
\text { distinguish between viral nucleic acid and } \\
\text { integrated viral sequences }\end{array}$ \\
\hline
\end{tabular}


TABLE 2

Novel plant viruses discovered using plant viral metagenomics ${ }^{a}$

\begin{tabular}{|c|c|c|c|c|c|}
\hline Virus taxonomy & Virus name & Plant host ${ }^{\mathrm{b}}$ & Nucleic acidc & $\begin{array}{l}\text { Accession } \\
\text { number }\end{array}$ & Reference \\
\hline $\begin{array}{l}\text { Alphaflexiviridae, } \\
\text { Marafivirus }\end{array}$ & $\begin{array}{l}\text { Ambrosia asymptomatic } \\
\text { virus } 1\end{array}$ & $\begin{array}{l}\text { Ambrosia } \\
\text { psilostachya* }\end{array}$ & VANA & KF421905 & (Dutta et al. 2014) \\
\hline $\begin{array}{l}\text { Geminiviridae, } \\
\text { Capulavirus }\end{array}$ & $\begin{array}{l}\text { Euphorbia caput-medusae } \\
\text { latent virus }\end{array}$ & $\begin{array}{l}\text { Euphorbia } \\
\text { caput-medusae* }\end{array}$ & VANA & $\begin{array}{l}\text { HF921459 } \\
\text { HF921477 } \\
\text { HF921460 }\end{array}$ & (Bernardo et al. 2013) \\
\hline $\begin{array}{c}\text { Geminiviridae, } \\
\text { Mastrevirus }\end{array}$ & $\begin{array}{l}\text { Sugarcane white streak } \\
\text { virus }\end{array}$ & Sugarcane & $\begin{array}{l}\text { VANA } \\
\text { and siRNA }\end{array}$ & KJ187748 & (Candresse et al. 2014) \\
\hline Gemycirculavirus & $\begin{array}{l}\text { Hordeum marinum Itera- } \\
\text { like densovirus }\end{array}$ & $\begin{array}{l}\text { Hordeum } \\
\text { marinum* (?) }\end{array}$ & VANA & KM576800 & (François et al. 2015) \\
\hline Gemycirculavirus & $\begin{array}{l}\text { Bromus-associated } \\
\text { circular DNA virus-1 }\end{array}$ & $\begin{array}{l}\text { Bromus } \\
\text { hordeaceus* (?) }\end{array}$ & VANA & KM510190 & $(\text { Kraberger et al. })^{d}$ \\
\hline Gemycirculavirus & $\begin{array}{l}\text { Trifolium associated } \\
\text { circular DNA virus-1 }\end{array}$ & $\begin{array}{l}\text { Trifolium } \\
\text { resupinatum* (?) }\end{array}$ & VANA & KP0054543 & $(\text { Kraberger et al. })^{d}$ \\
\hline $\begin{array}{r}\text { Luteoviridae, } \\
\text { Polerovirus }\end{array}$ & $\begin{array}{l}\text { Pepper yellow leaf } \\
\text { curl virus }\end{array}$ & Pepper & VANA & HM439608 & (Dombrovsky et al. 2013) \\
\hline $\begin{array}{r}\text { Secoviridae, } \\
\text { Cheravirus }\end{array}$ & Arracacha virus $B$ & Oxalis tuberosa & VANA & $\begin{array}{l}\text { JQ437415 } \\
\text { JQ581051 }\end{array}$ & (Adams et al. 2013b) \\
\hline $\begin{array}{r}\text { Secoviridae, } \\
\text { Nepovirus }\end{array}$ & $\begin{array}{l}\text { Potato black ringspot } \\
\text { virus-A8 }\end{array}$ & Arracacia spp. & VANA & $\begin{array}{l}\text { KC832889 } \\
\text { KC832891 }\end{array}$ & (Richards et al. 2014) \\
\hline $\begin{array}{r}\text { Secoviridae, } \\
\text { Nepovirus }\end{array}$ & $\begin{array}{l}\text { Potato black ringspot } \\
\text { virus-GAF14 }\end{array}$ & Arracacia spp. & VANA & $\begin{array}{l}\text { KC832888 } \\
\text { KC832895 } \\
\end{array}$ & (Richards et al. 2014) \\
\hline Gemycirculavirus & $\begin{array}{l}\text { Bromus-associated } \\
\text { circular DNA virus-2 }\end{array}$ & $\begin{array}{l}\text { Bromus } \\
\text { hordeaceus* (?) }\end{array}$ & Total DNA & KM510191 & $(\text { Kraberger et al. })^{d}$ \\
\hline Gemycirculavirus & $\begin{array}{l}\text { Bromus-associated } \\
\text { circular DNA virus-3 }\end{array}$ & $\begin{array}{l}\text { Bromus } \\
\text { hordeaceus* (?) }\end{array}$ & Total DNA & KM510192 & $(\text { Kraberger et al. })^{d}$ \\
\hline Gemycirculavirus & $\begin{array}{l}\text { Bromus-associated } \\
\text { circular DNA virus-4 }\end{array}$ & $\begin{array}{l}\text { Bromus } \\
\text { hordeaceus }^{*} \text { (?) }\end{array}$ & Total DNA & KP005454 & ${\text { (Kraberger et al. })^{d}}^{d}$ \\
\hline $\begin{array}{l}\text { Unclassified } \\
\text { ssDNA viruses }\end{array}$ & $\begin{array}{c}\text { Cassava associated } \\
\text { circular DNA virus } \\
\end{array}$ & Cassava & Total DNA & JQ412056 & (Dayaram et al. 2012) \\
\hline $\begin{array}{l}\text { Betaflexiviridae, } \\
\text { Capillovirus }\end{array}$ & Diuris virus $A$ & Diuris pedunculata* & Total RNA & JX173276 & (Wylie et al. 2013a) \\
\hline $\begin{array}{l}\text { Betaflexiviridae, } \\
\text { Capillovirus }\end{array}$ & Diuris virus $B$ & Diuris pedunculata* & Total RNA & JX173277 & (Wylie et al. 2013a) \\
\hline $\begin{array}{c}\text { Betaflexiviridae, } \\
\text { Carlaviruses }\end{array}$ & $\begin{array}{l}\text { Nerine latent virus- } \\
\text { Marijiniup4 }\end{array}$ & Hippeastrum sp.\# & Total RNA & JQ395043 & (Wylie et al. 2012a) \\
\hline $\begin{array}{l}\text { Betaflexiviridae, } \\
\text { Carlaviruses }\end{array}$ & $\begin{array}{l}\text { Nerine latent virus- } \\
\text { Marijiniup5 }\end{array}$ & Narcissus sp.\# & Total RNA & JQ395044 & (Wylie et al. 2012a) \\
\hline $\begin{array}{c}\text { Betaflexiviridae, } \\
\text { Chordovirus }\end{array}$ & Carrot chordovirus-1 & Carrot & Total RNA & KF533711 & (Adams et al. 2014b) \\
\hline $\begin{array}{c}\text { Betaflexiviridae, } \\
\text { Chordovirus }\end{array}$ & Carrot chordovirus-2 & Carrot & Total RNA & KF533710 & (Adams et al. 2014b) \\
\hline $\begin{array}{l}\text { Betaflexiviridae, } \\
\text { Trichovirus }\end{array}$ & Scaevola virus $A$ & Scaevola calliptera* & Total RNA & JN127346 & (Wylie et al. 2012a) \\
\hline $\begin{array}{l}\text { Bromoviridae, } \\
\text { Cucumovirus }\end{array}$ & $\begin{array}{l}\text { Gayfeather mild mottle } \\
\text { virus }\end{array}$ & Liatris spicata\# & Total RNA & $\begin{array}{l}\text { FM881899 } \\
\text { FM881900 } \\
\text { FM881901 }\end{array}$ & (Adams et al. 2009) \\
\hline $\begin{array}{c}\text { Closteroviridae, } \\
\text { Closterovirus }\end{array}$ & Carrot closterovirus 1 & Carrot & Total RNA & KF533697 & (Adams et al. 2014b) \\
\hline $\begin{array}{l}\text { Potyviridae, } \\
\text { Poacevirus }\end{array}$ & Caladenia virus A-KP2 & Caladenia arenicola* & Total RNA & JX156426 & (Wylie et al. 2012b) \\
\hline $\begin{array}{l}\text { Potyviridae, } \\
\text { Poacevirus }\end{array}$ & Caladenia virus $A-K P 3$ & Caladenia elastica* & Total RNA & JX156427 & (Wylie et al. 2012b) \\
\hline
\end{tabular}

(continued on next page)

\footnotetext{
a This table does not include the numerous viruses found through NGS that were not further characterized.

${ }^{b}$ Plants are crop, ornamental $(\#)$, or wild $\left({ }^{*}\right)$. ? indicates that the domestication status is not clear.

c Virion-associated nucleic acids (VANA), small interfering RNA (siRNA), and double-stranded RNA (dsRNA).

d Kraberger et al. refers to S. Kraberger, K. Farkas, P. Bernardo, C. Booker, G. R. Argüello-Astorga, F. Mesléard, D. P. Martin, P. Roumagnac, and A. Varsani, unpublished data).
} 
TABLE 2

(continued from preceding page)

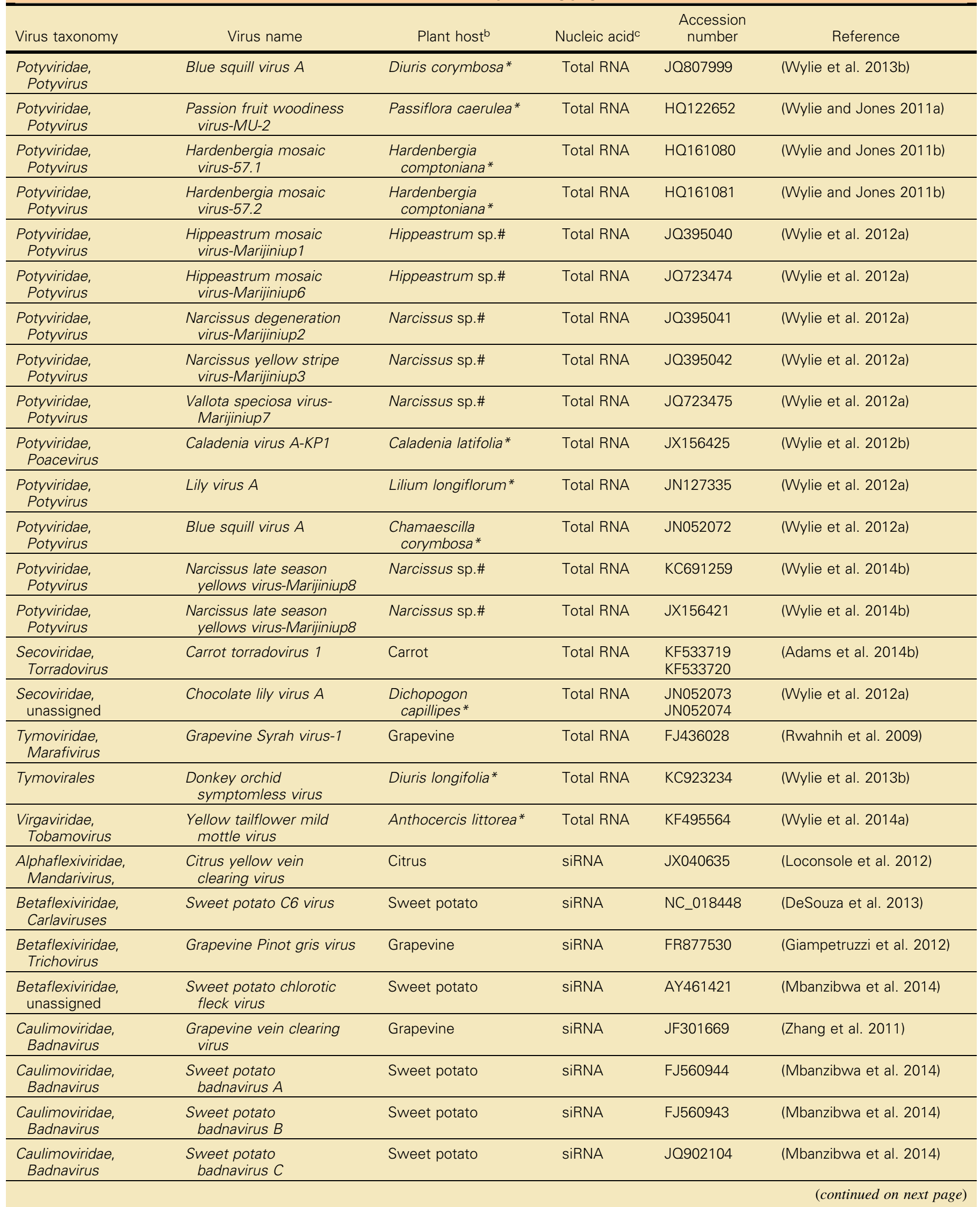


TABLE 2

(continued from preceding page)

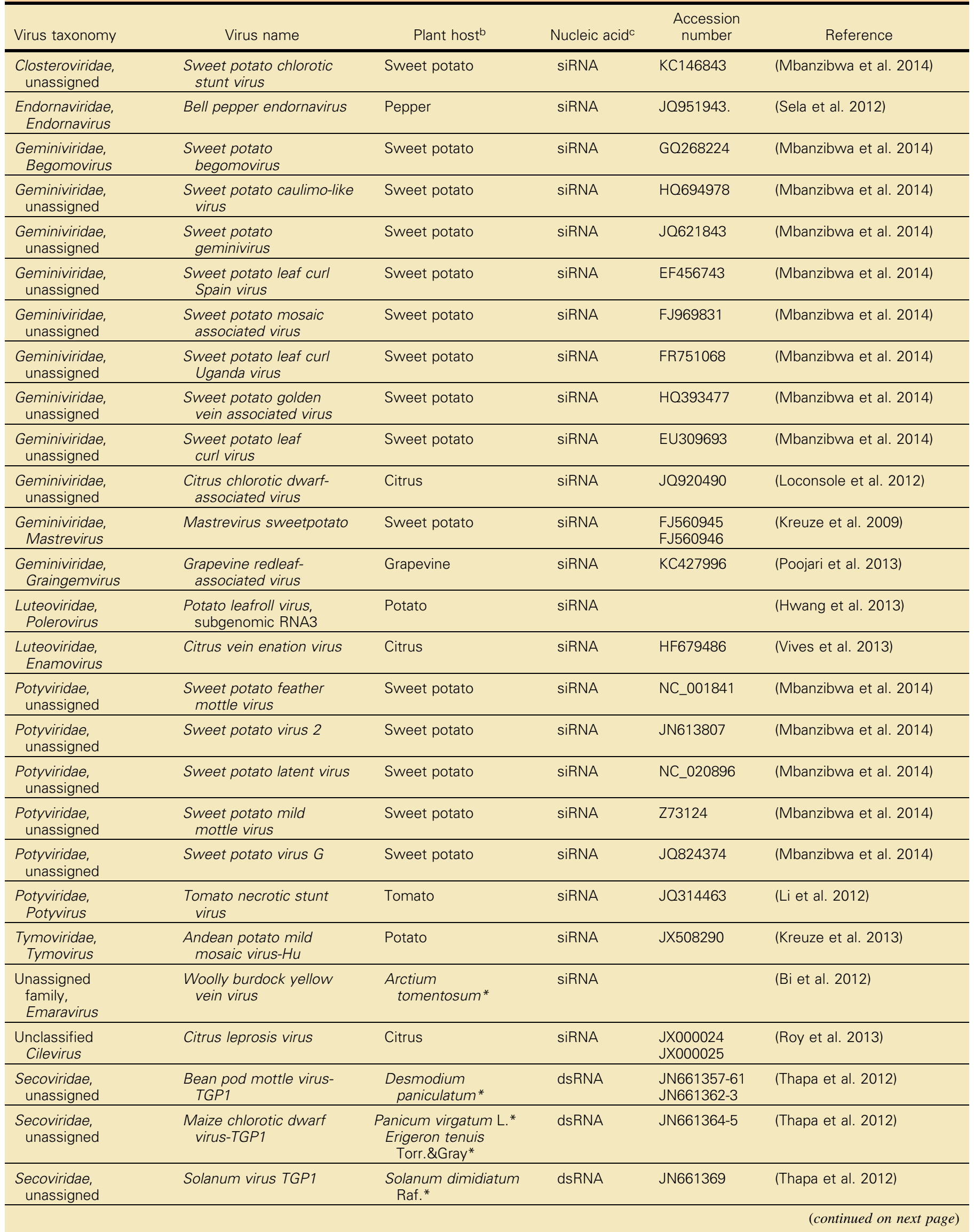


TABLE 2

(continued from preceding page)

\begin{tabular}{|c|c|c|c|c|c|}
\hline Virus taxonomy & Virus name & Plant host ${ }^{\mathrm{b}}$ & Nucleic acidc & $\begin{array}{l}\text { Accession } \\
\text { number }\end{array}$ & Reference \\
\hline $\begin{array}{l}\text { Secoviridae, } \\
\text { unassigned }\end{array}$ & Veronia virus TGP1 & $\begin{array}{l}\text { Veronia baldwinii } \\
\text { Torr. }{ }^{*}\end{array}$ & dsRNA & JN661369 & (Thapa et al. 2012) \\
\hline $\begin{array}{l}\text { Secoviridae, } \\
\text { unassigned }\end{array}$ & Asclepias virus TGP2 & $\begin{array}{l}\text { Multiple wild hosts, } \\
\text { see reference for } \\
\text { details }\end{array}$ & dsRNA & See reference & (Thapa et al. 2012) \\
\hline $\begin{array}{l}\text { Tombusviridae, } \\
\text { Panicovirus }\end{array}$ & $\begin{array}{l}\text { Paspalum asymptomatic } \\
\text { virus }\end{array}$ & $\begin{array}{l}\text { Paspalum setaceum } \\
\text { var. muehlenbergii* }\end{array}$ & dsRNA & $\begin{array}{l}\text { JX848616 } \\
\text { JX848617 } \\
\text { JX848618 } \\
\text { JX848619 }\end{array}$ & (Scheets 2013) \\
\hline $\begin{array}{l}\text { Tombusviridae, } \\
\text { Carmovirus }\end{array}$ & TGP carmovirus 1 & $\begin{array}{l}\text { Multiple wild hosts, } \\
\text { see reference for } \\
\text { details* }\end{array}$ & $\begin{array}{l}\text { dsRNA } \\
\text { and VANA }\end{array}$ & See reference & (Scheets et al. 2011) \\
\hline $\begin{array}{l}\text { Tombusviridae, } \\
\text { Carmovirus }\end{array}$ & TGP carmovirus 3 & $\begin{array}{l}\text { Multiple wild hosts, } \\
\text { see reference for } \\
\text { details* }\end{array}$ & $\begin{array}{l}\text { dsRNA } \\
\text { and VANA }\end{array}$ & See reference & (Scheets et al. 2011) \\
\hline
\end{tabular}

2009; Loconsole et al. 2012; Seguin et al. 2014; Zhang et al. 2011). The reason for this is thought to be because both coding and noncoding regions of circular viral dsDNA are transcribed in both orientations in the nucleus to generate dsRNA precursors of viral siRNAs (Seguin et al. 2014). However, no DNA viruses have been recovered from dsRNA-based analyses, so if these form they are likely very transient and do not accumulate to appreciable levels.

The biggest advantage of the siRNA approach is that it is very sensitive for detecting both known and unknown viruses within single plants. It can also be used to detect integrated endogenous viral elements (EVEs) if they are transcribed (see below).

The siRNA-based metagenomic approaches also have other disadvantages, not the least of which is that siRNA extraction involves cumbersome Trizol and CTAB-based protocols. Also, this approach may be problematic when used to detect viruses that either do not trigger silencing responses or that produce silencing suppressors. For example, viruses with dsRNA genomes do not expose any dsRNA to the cytoplasm of the cell. The dsRNA remains encapsidated with ssRNA being extruded from the capsid to serve as mRNA and pregenomic RNA that is packaged prior to secondstrand replication (Safari and Roossinck 2014). Many persistent viruses have this type of genome (Roossinck 2012a) and are found in plant meristems where most other viruses are controlled by silencing (Martín-Hernández and Baulcombe 2008). Of the known persistent plant viruses, only an endornavirus has ever been successfully assembled from siRNAs (Table 2) - a fact that is unsurprising since these viruses are unencapsidated with their genomes generally being found in the cytoplasm as dsRNA replicative intermediates (Roossinck et al. 2011).

In silico methods. In addition to in vitro metagenomic approaches, "in silico cloning" from expressed sequence tag (EST) databases has proved to be an effective means of discovering new viruses and virus-like entities (Liu et al. 2012; Mambole et al. 2014). This approach is based on the hypothesis that plant samples that are used to construct cDNA libraries for EST sequencing may be asymptomatically infected by plant viruses such that viral RNAs will sometimes be randomly cloned and sequenced together with host mRNAs. A broad study of EST databases revealed the putative presence in cDNA libraries generated from several monocots and eudicots of more than 100 sequences detectably related to plant viruses in the families Endornaviridae, Chrysoviridae, Partitiviridae, and Totiviridae (Liu et al. 2012). Although relying on the serendipitous inclusion of plant virus sequences in plant cDNA libraries may seem like an inefficient approach to the discovery of new virus species, it is relatively simple and inexpensive to continue searching for virus-like sequences within the vast volumes of EST, siRNA, and RNAseq data that are released into the public domain each year. The shortcomings of this method are that there is no easy way to determine if the virus-like sequences are derived from viruses or integrated viral sequences that are common in genomes; many virus-derived RNAs do not have poly-A tails, so they would not be detected in EST libraries; and in plants where the genome is available, ESTs that are not found in the genome are often deleted before publication of the library.

\section{DATA ANALYSIS}

Underlying all of the plant virus metagenomic approaches are analyses of sequence data. For the field of viral metagenomics in general, this is an area where a lot more advances are needed. Most standard tools for NGS analysis were developed for other systems and need to be modified to better suit the analyses of viruses. Details of some of the problems with applying these approaches in virological studies have been recently reviewed (Roossinck 2012b; Stobbe and Roossinck 2014).

De novo assembly of sequence reads. One of the main differences between viruses and other microbes is that degrees of sequence variation within virus populations infecting even an individual host can be much greater than for other biological entities. As a result the stringency with which sets of overlapping DNA reads that together represent a consensus sequence (contigs) are built should be considerably lower than those used to assemble cellular genomes. However, while relaxing these criteria will often yield larger contigs, it will also increase the probability that individual contigs will end up being chimeras of multiple genetically distinct genomes, artificially generating recombinant genomes. In silico recombination, like genuine recombination, will negatively impact the accuracy of phylogenetic tree construction and other sequence analysis methods. Testing for the presence of recombination, and taking steps to account for its occurrence, should be a component of all NGS-based virus metagenomic analysis pipelines (Martin et al. 2011).

Sequence assignment and taxonomy. Once NGS reads are assembled into partial virus genome contigs these are usually classified 
into families, genera, species or other functional ad hoc operational taxonomic units (OTUs) using BLAST-based methodologies (Stobbe et al. 2013). Unfortunately, most currently published metagenome studies don't take the next step and try to classify the sequences phylogenetically so as to determine whether they fall within the bounds of known species, genera or families. It is important to stress that detectable sequence similarity does not necessarily imply biological similarity. Frequently, environmental or host-associated viruses, purportedly belonging to particular families ( $\mathrm{Ng}$ et al. 2012), should in many cases be assigned to completely new families.

Even when sequence classifications are rigorously carried out using phylogenetic approaches in addition to BLAST, classification problems can still arise when different parts of sequences seem to be related to viruses belonging to completely unrelated families (Deimer and Stedman 2012; Roux et al. 2013). Since multiple instances of such hybrid viruses have been detected in environmental metagenomic screens it is plausible that analogous hybrid viruses might eventually also be detected in plant virus metagenomic screens.

Gaps in publicly available databases. In addition to issues with the quality of NGS data, the size and accuracy of the viral genome contigs and the reliability of their classification, probably the biggest problem encountered in metagenomic studies in general is that much of the data that are generated cannot even be studied. This is simply because many (and in some cases most) of the sequence reads obtained have no detectable homologs in the sequence databases. Even when enriching specifically for nucleic acids associated with viruses, more than $60 \%$ of NGS reads obtained in some plant metagenomic projects are not detectably homologous to any other known nucleotide or amino acid sequences. These difficulties remain even when using sensitive searches like tBLASTx that compares translated input sequences and all possible translations of nucleotide sequences in the database. This implies that there are likely large numbers of viruses that we presently cannot even recognize as such.

\section{APPLICATIONS OF VIRAL METAGENOMICS TO PLANT PATHOLOGY}

Plant viral metagenomics has dramatically challenged the limits of our knowledge of plant virus biodiversity. In addition to many new viruses discovered in cultivated and uncultivated plants (Table 2), plant viruses have also been found in a number of other organisms and environments (Roossinck 2012b).

Despite the deluge of novel plant viruses that metagenomics has helped uncover, the potential utility of this approach in plant virus diagnostics is still being debated (reviewed in Massart et al. 2014). To date, very few studies have deliberately used metagenomics for cataloguing the viromes of individual plants from a purely diagnostic perspective. The roll-out of diagnostic metagenomic implementations is primarily being hampered by issues around costs, portability, and standardization. Standardization of detection sensitivity thresholds is a particularly important issue since some degree of background sequence contamination is likely unavoidable for such sensitive methods (Massart et al. 2014). Standard lowcost metagenomic protocols with high degrees of sensitivity to true positives yet low degrees of sensitivity to contamination will be a major milestone in the future of plant diagnostics.

Importantly, a few studies have already begun paving the way. For instance, a combined siRNA/VANA-based metagenomic approach was recently used for the detailed identification and characterization of viruses infecting quarantined sugarcane plants (Candresse et al. 2014). This study revealed the presence of a novel mastrevirus (family Geminiviridae), Sugarcane white streak virus, which had so far escaped routine quarantine detection assays, possibly because it was present in mixed infection with another mastrevirus, Sugarcane streak Egypt virus (Candresse et al. 2014).
Another study, using a combination of total RNA and dsRNA metagenomic approaches, focused on phytosanitation risks posed by the international fresh produce trade. It found 41 distinct virus isolates, including potyviruses, carlaviruses, and allexiviruses, within 10 garlic bulbs imported into Australia from Europe, America, and Asia (Wylie et al. 2014c).

Both of these studies underline the potential advantages of plant virus metagenomics as a means of assessing imported fresh produce so as to substantially reduce the numbers of unintercepted virus pathogens passing through plant quarantine stations and biological resource centers (Candresse et al. 2014; Wylie et al. 2014c).

Besides providing a better way to solve ancient or emerging etiologic enigmas (Adams et al. 2013b, 2014a; Rwahnih et al. 2009), plant viral metagenomics is, for the first time, set to reveal the contribution of plant viruses to global ecosystems. Crucially, only a very small fraction of wild plants display any obvious evidence of virus infections. For example, despite only $2.3 \%$ of plant specimens collected in the Tallgrass Prairie Preserve in northeastern Oklahoma having any outward signs of virus infection, viruses were discovered in $25 \%$ of these (Muthukumar et al. 2009). Although this may imply that uncultivated hosts are in general highly tolerant of viral infections, it is more likely that viruses are simply not particularly pathogenic within their natural ecological contexts.

These hypotheses are not mutually exclusive and evidence supporting both has come from more in depth studies of two highly divergent viruses infecting uncultivated plants: one a geminivirus (Bernardo et al. 2013) and the other a tymovirus (Min et al. 2012). While both viruses caused asymptomatic infections in their uncultivated natural hosts, the tymovirus caused a symptomatic infection (chlorosis, mottle, and mosaic) in Nicotiana benthamiana (Min et al. 2012) and the geminivirus caused severe infections in tomato (Bernardo et al. 2013).

Despite neither being obviously pathogenic in their natural hosts, both viruses have the potential to cause severe disease in "unnatural" cultivated host species: all that is required is either the importation of exotic hosts into their environment, or the exportation of these viruses into foreign environments. This observation is consistent with the hypothesis that disease is an evolutionarily disadvantageous state for both viruses and their hosts and generally only occurs as a result of maladapted interactions within newly formed parasitic relationships (Bao and Roossinck 2013). Beyond disease and parasitism, metagenomics may reveal a multitude of mutualistic relationships between viruses and plants (Roossinck 2011, 2013).

Metagenomic-oriented approaches are ideally suited to test such hypotheses. They provide the means for the long-term surveillance of viromes for sporadic host-jumping events, and could be used to detect the progress of host-adaptation during the process of hostrange modification. Coupled with laboratory evaluation of viruses that appear to be in the process of host range shifting, such studies would greatly advance our understanding of the processes whereby viruses emerge from their natural hosts to become economically significant threats to agricultural production.

Through viral metagenomics, plant pathology has the opportunity to start looking beyond cropping systems. Outside of natural and managed plant ecosystems, plant viruses have been found associated with a variety of nonplant organisms in a number of different environments (Roossinck 2012b). For example, besides infectious PMMV having been found in human feces (Zhang et al. 2006), it has been detected at high concentrations in river and seawater that receives effluent from waste and drinking water treatment stations (Hamza et al. 2011; Haramoto et al. 2013; Rosario et al. 2009b).

Metagenomics has revealed unexpected putative modes of plant virus transmission that fall far outside the classical plant-virus-insect interaction framework. The current plant virus transmission dogma 
that places insects as the dominant transmission vectors may eventually need to be modified to include other secondary vectors such as large herbivores (Ng et al. 2014), bats (Donaldson et al. 2010), rodents (Phan et al. 2011), near-surface atmosphere (Whon et al. 2012), or irrigation water (Hamza et al. 2011; Haramoto et al. 2013; Rosario et al. 2009a). Metagenomics is ideally suited to unravel the relative impacts of these alternative transmission processes and trace the global circulation of plant viruses at the ecosystem level.

\section{CONCLUSIONS}

Despite rapid progress over the past decade, the field of plant viral metagenomics is still in its infancy. Probably the most important message from current studies is that we still know very little (Stobbe and Roossinck 2014). Beyond virus transmission, host range overlaps, interspecies interactions, and ecological prevalence, plant viral metagenomics stands poised to begin answering even bigger questions. What impacts do plant viruses have on global ecosystems? Are plant viruses a healthy component of these ecosystems? How will climate change and human-mediated disturbances modify or alter the roles of plant viruses within these ecosystems? Addressing these questions will likely modify our conservation policies to account for viral biodiversity as an important component of the ecosystem "holobiont." Metagenomics will also enable long-term surveillance of viromes within wild and cultivated hosts in order to predict and ultimately interrupt the processes by which plant viruses breach the barriers separating their natural wild hosts and their prospective cultivated hosts.

\section{ACKNOWLEDGMENTS}

We thank P. Bernardo, E. Fernandez, and D. Filloux for their invaluable help in achieving the large-scale VANA-based ecogenomic studies conducted in Camargue and Western Cape regions. M. J. Roossinck acknowledges the National Science Foundation grant numbers EF-0627108, EPS-0447262, IOS-0950579, and IOS1157148 and the United States Department of Agriculture grant number OKLR-2007-01012 for previous and continuing research support, and the Pennsylvania State University.

\section{LITERATURE CITED}

Adams, I. P., Diano, D. W., Kinyua, Z. M., Wangai, A., Kimani, E., Phiri, N., Reeder, R., Harju, V., Glover, R., Hany, U., Souza-Richards, R., Nath, P. D., Nixon, T., Fox, A., Barnes, A., Smith, J., Skelton, A., Thwaites, R., Mumford, R., and Boonham, N. 2013a. Use of next-generation sequencing for the identification and characterization of Maize chlorotic mottle virus and Sugarcane mosaic virus causing maize lethal necrosis in Kenya. Plant Pathol. 63:741-749.

Adams, I. P., Fai, S., Deka, M., Harju, V., Hodges, T., Hayward, G., Skelton, A., Fox, A., and Boonham, N. 2014a. Genome sequence of vanilla distortion mosaic virus infecting Coriandrum sativum. Arch. Virol. 159: 3463-3465.

Adams, I. P., Glover, R., Souza-Richards, R., Bennett, S., Hany, U., and Boonham, N. 2013b. Complete genome sequence of arracacha virus B: A novel cheravirus. Arch. Virol. 158:909-913.

Adams, I. P., Glover, R. H., Monger, W. A., Mumford, R., Jackeviciene, E., Navalinskiene, M., Samuitiene, M., and Boonham, N. 2009. Nextgeneration sequencing and metagenomic analysis: A universal diagnostic tool in plant virology. Mol. Plant Pathol. 10:537-545.

Adams, I. P., Skelton, A., Macarthur, R., Hodges, T., Hinds, H., Flint, L., Nath, P. D., Boonham, N., and Fox, A. 2014b. Carrot yellow leaf virus is associated with carrot internal necrosis. PLoS One 9:e109125.

Allander, T., Emerson, S. U., Engle, R. E., Purcell, R. H., and Bukh, J. 2001. A virus discovery method incorporating DNase treatment and its application to the identification of two bovine parvovirus species. Proc. Natl. Acad. Sci. USA 98:11609-11614.

Bao, X., and Roossinck, M. J. 2013. A life history view of mutualistic viral symbioses: Quantity or quality for cooperation? Curr. Op. Microbiol. 16: 514-518.
Bergh, Ø., Børsheim, K. Y., Bratbak, G., and Heldal, M. 1989. High abundance of viruses in aquatic environments. Nature 340:467-468.

Bernardo, P. 2014. Ecologie, diversité et découverte de phytovirus à l'échelle de deux agro-écosystèmes dans un cadre spatio-temporel à l'aide de la géométagénomique. Ph.D. Thesis, University of Montellier II.

Bernardo, P., Golden, M., Akram, M., Maimuddin, N. M., Fernandez, E., Granier, M., Rebelo, A. G., Peterschmitt, M., Martin, D. P., and Roumagnac, P. 2013. Identification and characterization of a highly divergent geminivirus: Evolutionary and taxonomic implications. Virus Res. 177:35-45.

Bi, Y., Tugume, A. K., and Valkonen, J. P. T. 2012. Small-RNA deep sequencing reveals Arctium tomentosum as a natural host of Alstroemeria virus $X$ and a new putative Emaravirus. PLoS One 7:e42758.

Breitbart, M., and Rohwer, F. 2005. Here a virus, there a virus, everywhere the same virus? Trends Microbiol. 13:278-284.

Breitbart, M., Salamon, P., Andresen, B., Mahaffy, J. M., Segall, A. M., Mead, D., and Azam, F. 2002. Genomic analysis of uncultured marine viral communities. Proc. Natl. Acad. Sci. USA 99:14250-14255.

Candresse, T., Filloux, D., Muhire, B., Julian, C., Galzi, S., Fort, G., Bernardo, P., Daugrois, J.-H., Fernandez, E., Martin, D. P., Varsani, A., and Roumagnac, P. 2014. Appearances can be deceptive: Revealing a hidden viral infection with deep sequencing in a plant quarantine context. PLoS One 7:e42758.

Dayaram, A., Opong, A., Jäschke, A., Hadfield, J., Baschiera, M., Dobson, R. C. J., Offei, S. K., Shepherd, D. N., Martin, D. P., and Varsani, A. 2012. Molecular characterization of a novel cassava associated circular ssDNA virus. Virus Res. 166:130-135.

Deimer, G. S., and Stedman, K. M. 2012. A novel virus genome discovered in an extreme environment suggests recombination between unrelated groups of RNA and DNA viruses. Biol. Direct 7:13.

DeSouza, J., Fuentes, S., Savenkov, E. I., Cuellar, W., and Kreuze, J. F. 2013. The complete nucleotide sequence of a sweet potato C6 virus: A carlavirus lacking a cysteine-rich protein. Arch. Virol. 158:1393-1396.

Diaz-Ruiz, J. R., and Kaper, J. M. 1978. Isolation of viral double-stranded RNAs using a $\mathrm{LiCl}$ fractionation procedure. Prep. Biochem. 8:1-17.

Dodds, J. A., Morris, T. J., and Jordan, R. L. 1984. Plant viral double-stranded RNA. Annu. Rev. Phytopathol. 22:151-168.

Dombrovsky, A., Glanz, E., Lachman, O., Sela, N., Doron-Faigenboim, A., and Antignus, Y. 2013. The complete genomic sequence of Pepper yellow leaf curl virus (PYLCV) and its implications for our understanding of evolution dynamics in the genus Polerovirus. PLoS One 8:e70722.

Donaire, L., Wang, Y., Gonzalez-Ibeas, D., Mayer, K. F., Aranda, M. A., and Llave, C. 2009. Deep-sequencing of plant viral small RNAs reveals effective and widespread targeting of viral genomes. Virology 392:203-214.

Donaldson, E. F., Haskew, A. N., Gates, J. E., Huynh, J., Moore, C. J., and Frieman, M. B. 2010. Metagenomic analysis of the viromes of three North American bat species: Viral diversity among different bat species that share a common habitat. J. Virol. 84:13004-13019.

Dutta, M., Bashir, N. S., Palmer, M. W., and Melcher, U. 2014. Genomic characterization of Ambrosia asymptomatic virus 1 and evidence of other Tymovirales members in the Oklahoma tallgrass prairie revealed by sequence analysis. Arch. Virol. 159:1755-1764.

François, S., Bernardo, P., Filloux, D., Roumagnac, P., Yavercovski, N., Froissart, R., and Ogliastro, M. 2015. A novel Itera-like densovirus isolated by viral metagenomics from the sea barley Hordeum marinum. Genome Announcements. 2(6):e01196-14.

Giampetruzzi, A., Roumi, V., Roberto, R., Malossini, U., Yoshikawa, N., LaNotte, P., Terlizzi, F., Credi, R., and Saidarelli, P. 2012. A new grapevine virus discovered by deep sequencing of virus- and viroid-derived small RNAs in Cv Pinot gris. Virus Res. 163:262-268.

Hagen, C., Frizzi, A., Kao, J., Jia, L., Huang, M., Zhang, Y., and Huang, S. 2011. Using small RNA sequences to diagnose, sequence, and investigate the infectivity characteristics of vegetable-infecting viruses. Arch. Virol. 156:1209-1216.

Hall, R. J., Wang, J., Todd, A. K., Bissielo, A. B., Yen, S., Strydom, H., Moore, N. E., Ren, X., Huang, Q. S., Carter, P. E., and Pearcey, M. 2014. Evaluation of rapid and simple techniques for the enrichment of viruses prior to metagenomic virus discovery. J. Virol. Methods 195:194-204.

Hamza, I. A., Jurzik, L., Überla, K., and Wilhelm, M. 2011. Evaluation of pepper mild mottle virus, human picobirnavirus and Torque teno virus as indicators of fecal contamination in river water. Water Res. 45: $1358-1368$.

Handelsman, J. 2004. Metagenomics: Application of genomics to uncultured microorganisms. Microbiol. Mol. Biol. Rev. 68:669-685.

Handelsman, J., Rondon, M. R., Brady, S. F., Clardy, J., and Goodman, R. M. 1998. Molecular biological access to the chemistry of unknown soil microbes: A new frontier for natural products. Chem. Biol. 5:R245R249. 
Haramoto, E., Kitajima, M., Kishida, N., Konno, Y., Katayama, H., Asami, M., and Akiba, M. 2013. Occurrence of pepper mild mottle virus in drinking water sources in Japan. Appl. Environ. Microbiol. 79:7413-7418.

Hwang, Y. T., Kalischuk, M., Fusaro, A. F., Waterhouse, P. M., and Kawchuk, L. 2013. Small RNA sequencing of Potato leafroll virus-infected plants reveals an additional subgenomic RNA encoding a sequence-specific RNAbinding protein. Virology 438:61-69.

Jones, M. S., Kapoor, A., Lukashov, V. V., Simmonds, P., Hecht, F., and Delwart, E. 2005. New DNA viruses identified in patients with acute viral infection syndrome. J. Virol. 79:8230-9236.

Kreuze, J., Koenig, R., DeSouza, J., Vetten, H. J., Muller, G., Flores, B., Ziebell, H., and Cuellar, W. 2013. The complete genome sequences of a Peruvian and a Colombian isolate of Andean potato latent virus and partial sequences of further isolates suggest the existence of two distinct potato-infecting tymovirus species. Virus Res. 173:431-435.

Kreuze, J. F., Perez, A., Untiveros, M., Quispe, D., Fuentes, S., Barker, I., and Simon, R. 2009. Complete viral genome sequence and discovery of novel viruses by deep sequencing of small RNAs: A generic method for diagnosis, discovery and sequencing of viruses. Virology 388:1-7.

Li, R., Gao, S., Hernandez, A. G., Wechter, W. P., Fei, Z., and Ling, K.-S. 2012. Deep sequencing of small RNAs in tomato for virus and viroid identification and strain differentiation. PLoS One 7:e37127.

Liu, H., Fu, Y., Xie, J., Cheng, J., Ghabrial, S. A., Li, G., Yi, X., and Jiang, D. 2012. Discovery of novel dsRNA viral sequences by in silico cloning and implications for viral diversity, host range and evolution. PLoS One 7: e421747.

Loconsole, G., Önelge, N., Potere, P., Giampetruzzi, A., Bozan, O., Satar, S., DeStradis, A., Savino, V., Yokomi, R. K., and Saponari, M. 2012. Identification and characterization of Citrus yellow vein clearing virus, a putative new member of the genus Mandarivirus. Phytopathology 102:1168-1175.

MacDiarmid, R., Rodoni, B., Melcher, U., Ochoa-Corona, F., and Roossinck, M. 2013. Biosecurity implications of new technology and discovery in plant virus research. PLoS Pathog. 7:e37127.

Mambole, I. A., Bonheur, L., Dumas, L. S., Filloux, D., Gomez, R.-M., Faure, C., Lange, D., Anzala, F., Pavis, C., Marais, A., Roumagnac, P., Candresse, T., and Teycheney, P.-Y. 2014. Molecular characterization of yam virus I, a new potexvirus infecting yams (Discorea spp.) and evidence for the existence of at least three distinct potexviruses infecting yams. Arch. Virol. 159:3421-3426.

Martin, D. P., Lemey, P., and Posada, D. 2011. Analyzing recombination in nucleotide sequences. Mol. Ecol. Resour. 11:943-955.

Martín-Hernández, A. M., and Baulcombe, D. C. 2008. Tobacco rattle virus 16-kilodalton protein encodes a suppressor of RNA silencing that allows transient viral entry in meristems. J. Virol. 82:4064-4071.

Massart, S., Olmos, A., Jijakli, H., and Candresse, T. 2014. Current impact and future directions of high throughput sequencing in plant virus diagnostics. Virus Res. 188:90-96.

Mbanzibwa, D. R., Tugume, A. K., Chiunga, E., Mark, D., and Tairo, F. D. 2014. Small RNA deep sequencing-based detection and further evidence of DNA viruses infection sweetpotato plants in Tanzania. Ann. Appl. Biol. 165:329-339.

Melcher, U., Muthukumar, V., Wiley, G. B., Min, B. E., Palmer, M. W., Verchot-Lubicz, J., Ali, A., Nelson, R. S., Roe, B. A., Thapa, V., and Pierce, M. L. 2008. Evidence for novel viruses by analysis of nucleic acids in viruslike particle fractions from Ambrosia psilostachya. J. Virol. Methods 152: 49-55.

Min, B.-E., Feldman, T. S., Ali, A., Wiley, G., Muthukumar, V., Roe, B. A., Roossinck, M., Melcher, U., Palmer, M. W., and Nelson, R. S. 2012. Molecular characterization, ecology, and epidemiology of a novel tymovirus in Asclepias viridis from Oklahoma. Phytopathology 102:166-176.

Monger, W. A., Alical, T., Ndunguru, J., Kinyua, Z. M., Potts, M., Reeder, R. H., Miano, D. W., Adams, I. P., Boonham, N., Glover, R. H., and Smith, J. 2010. The complete genome sequence of the Tanzanian strain of Cassava brown streak virus and comparison with the Ugandan strain sequence. Arch. Virol. 155:429-433.

Muthukumar, V., Melcher, U., Pierce, M., Wiley, G. B., Roe, B. A., Palmer, M. W., Thapa, V., Ali, A., and Ding, T. 2009. Non-cultivated plants of the Tallgrass Prairie Preserve of northeastern Oklahoma frequently contain virus-like sequences in particulate fractions. J. Virol. Methods 141:169173.

Ng, T. F. F., Chen, L.-F., Zhou, Y., Shapiro, B., Stiller, M., Heintzman, P. D., Varsani, A., Kondov, N. O., Wong, W., Dent, X., Andrews, T. D., Moorman, B. J., Meulendyk, T., MacKay, G., Gilbertson, R. L., and Delwart, E. 2014. Preservation of viral genomes in 700-y-old caribou feces from a subarctic ice patch. Proc. Natl. Acad. Sci. USA 111:16842-16847.

Ng, T. F. F., Manire, C., Borrowman, K., Langer, T., Ehrhart, L., and Breitbart, M. 2009. Discovery of a novel single-stranded DNA virus from a sea turtle fibropapilloma by using viral metagenomics. J. Virol. 83:2500-2509.
Ng, T. F. F., Marine, R., Wang, C., Simmonds, P., Kapusinszky, B., Bodhidatta, L., Oderinde, B. S., Wommack, K. E., and Delward, E. 2012. High variety of known and new RNA and DNA viruses of diverse origins in untreated sewage. J. Virol. 86:12161-12175.

Pace, N. R., Stahl, D. A., Lane, D. J., and Olsen, G. J. 1985. Analyzing natural microbial populations by rRNA sequences. ASM News 51:4-12.

Phan, T. G., Kapusinszky, B., Wang, C., Rose, R. K., Lipton, H. L., and Delwart, E. L. 2011. The fecal viral flora of wild rodents. PLoS Pathog. 7: e102218.

Poojari, S., Alabi, O. J., Fofanov, V. Y., and Naidu, R. A. 2013. A leafhoppertransmissible DNA virus with novel evolutionary lineage in the family Geminiviridae implicated in grapevine redleaf disease by next-generation sequencing. PLoS One 8:e64194.

Proctor, L. M., and Fuhrman, J. A. 1990. Viral mortality of marine bacteria and cyanobacteria. Nature 343:60-62.

Richards, R. S., Adams, I. P., Kreuze, J. F., DeSouza, J., Cuellar, W., Dullemans, A. M., VanDerVlugt, R. A. A., Glover, R., Hany, U., Dickinson, M., and Boonham, N. 2014. The complete genome sequences of two isolates of potato black ringspot virus and their relationship to other isolates and nepoviruses. Arch. Virol. 159:811-815.

Riesenfeld, C. S., Schloss, P. D., and Handelsman, J. 2004. Metagenomics: Genomic analysis of microbial communities. Annu. Rev. Genet. 38: $525-552$

Roossinck, M. J. 2011. The good viruses: Viral mutualistic symbioses. Nat. Rev. Microbiol. 9:99-108.

Roossinck, M. J. 2012a. Persistent plant viruses: Molecular hitchhikers or epigenetic elements? Pages 177-186 in: Viruses: Essential Agents of Life. G. Witzany, ed. Springer, Dordrecht, the Netherlands.

Roossinck, M. J. 2012b. Plant virus metagenomics: Biodiversity and ecology. Annu. Rev. Genet. 46:357-367.

Roossinck, M. J. 2013. Plant virus ecology. PLoS Pathog. 9:e1003304.

Roossinck, M. J. 2014. Metagenomics of plant and fungal viruses reveals an abundance of persistent lifestyles. Front. Microbiol. 5:767.

Roossinck, M. J. 2015. A new look at plant viruses and their potential beneficial roles in crops. Mol. Plant Pathol. 16:231-233.

Roossinck, M. J., Sabanadzovic, S., Okada, R., and Valverde, R. A. 2011. The remarkable evolutionary history of endornaviruses. J. Gen. Virol. 92: 2674-2678.

Roossinck, M. J., Saha, P., Wiley, G. B., Quan, J., White, J. D., Lai, H., Chavarría, F., Shen, G., and Roe, B. A. 2010. Ecogenomics: Using massively parallel pyrosequencing to understand virus ecology. Mol. Ecol. 19: 81-88.

Rosario, K., Nilsson, C., Lim, Y. W., Ruan, Y., and Breitbart, M. 2009a. Metagenomic analysis of viruses in reclaimed water. Environ. Microbiol. 11:2806-2820.

Rosario, K., Symonds, E. M., Sinigalliano, C., Steward, J., and Breitbart, M. 2009b. Pepper mild mottle virus as an indicator of fecal pollution. Appl. Environ. Microbiol. 75:7261-7267.

Roux, S., Enault, F., Brommer, G., Vaulot, D., Forterre, P., and Krupovic, M. 2013. Chimeric viruses blur the borders between the major groups of eukaryotic single-stranded DNA viruses. Nat. Commun. 4:2700.

Roy, A., Shao, J., Hartung, J. S., Schneider, W., and Briansky, R. H. 2013. A case study on discovery of novel Citrus Leprosis virus cytoplasmic type 2 utilizing small RNA libraries by next generation sequencing and bioinformatic analyses. J. Data Min. Genomics Proteomics 4:1000129.

Rusch, D. B., Halpern, A. L., Sutton, G., Heidelberg, K. B., Williamson, S., Yooseph, S., Wu, D., Eisen, J. A., Hoffman, J. M., Remington, K., Beeson, K., Tran, B., Smith, H., Baden-Tillson, H., Stewart, C., Thorpe, J., Freeman, J., Andrews-Pfannkoch, C., Venter, J. E., Li, K., Kravitz, S., Heidelberg, J. F., Utterback, T., Rogers, Y.-H., Falcón, L. I., Souza, V., Bonilla-Rosso, G., Eguiarte, L. E., Karl, D. M., Sathyendranath, S., Platt, T., Bermingham, E., Gallardo, V., Tamayo-Castillo, G., Ferrari, M. R., Strausberg, R. L., Nealson, K., Friedman, R., Frazier, M., and Venter, J. C. 2007. The Sorcerer II Global Ocean Sampling Expedition: Northwest Atlantic through eastern tropical Pacific. PLoS Biol. 5:e77.

Rwahnih, M. A., Daubert, S., Golino, D., and Rowhani, A. 2009. Deep sequencing analysis of RNAs from a grapevine showing Syrah decline symptoms reveals a multiple virus infection that includes a novel virus. Virology 387:395-401.

Safari, M., and Roossinck, M. J. 2014. How does the genome structure and lifestyle of a virus affect its population variation? Curr. Opin. Virol. 9: $39-44$.

Scheets, K. 2013. Infectious transcripts of an asymptomatic panicovirus identified from a metagenomic survey. Virus Res. 176:161-168.

Scheets, K., Blinkova, O., Melcher, U., Palmer, M., Wiley, G. B., Ding, T., and Roe, B. A. 2011. Detection of members of the Tombusviridae in the Tallgrass Prairie Preserve, Osage County, Oklahoma, USA. Virus Res. 160: 256-263. 
Schmidt, T. M., DeLong, E. F., and Pace, N. R. 1991. Analysis of a marine picoplankton community by $16 \mathrm{~S}$ rRNA gene cloning and sequencing. J. Bacteriol. 173:4371-4378.

Seguin, J., Rajeswaran, R., Malpica-López, N., Martin, R. R., Kasschau, K., Dolja, V. V., Otten, P., Farinelli, L., and Pooggin, M. M. 2014. De novo reconstruction of consensus master genomes of plant RNA and DNA viruses from siRNAs. PLoS One 9:e88513.

Sela, N., Luria, N., and Dombrovsky, A. 2012. Genome assembly of bell pepper endornavirus from small RNA. J. Virol. 86:7721.

Sharpton, T. J. 2014. An introduction to the analysis of shotgun metagnomic data. Front. Plant Sci. 5:209.

Stobbe, A. H., Daniels, J., Espindola, A. S., Verma, R., Melcher, U., Ochoa-Corona, F., Garzon, C., Fletcher, J., and Schneider, W. 2013. E-probe diagnostic nucleic acid analysis (EDNA): A theoretical approach for handling of next generation sequencing data for diagnostics. J. Microbiol. Methods 94:356-366.

Stobbe, A. H., and Roossinck, M. J. 2014. Plant virus metagenomics: What we know and why we need to know more. Front. Plant Sci. 5:150.

Suttle, C. A. 2005. Viruses in the sea. Nature 437:356-361.

Thapa, V., Melcher, U., Wiley, G. B., Doust, A., Palmer, M. W., Roewe, K., Roe, B. A., Shen, G., Roossinck, M. J., Wang, Y. M., and Kamath, N. 2012. Detection of members of the Secoviridae in the Tallgrass Prairie Preserve in Osage County, Oklahoma, USA. Virus Res. 167:34-42.

Tseng, C.-H., and Tang, S.-L. 2014. Marine microbial metagenomics: From individual to the environment. Int. J. Mol. Sci. 15:8878-8892.

Vives, M. C., Velázquez, K., Pina, J. A., Moreno, P., Guerri, J., and Navarro, L. 2013. Identification of a new enamovirus associated with citrus vein enation disease by deep sequencing of small RNAs. Phytopathology 103: 1077-1086.

Whon, T. W., Kim, M.-S., Roh, S. W., Shin, N.-R., Lee, H.-W., and Bae, J. W. 2012. Metagenomic characterization of airborne viral DNA diversity in the near-surface atmosphere. J. Virol. 86:8221-8231.

Wren, J. D., Roossinck, M. J., Nelson, R. S., Sheets, K., Palmer, M. W., and Melcher, U. 2006. Plant virus biodiversity and ecology. PLoS Biol. 4:e80.

Wylie, S. J., and Jones, M. G. K. 2011a. The complete genome sequence of a Passion fruit woodiness virus isolate from Australia determined using deep sequencing, and its relationship to other potyviruses. Arch. Virol. 156: 479-482.

Wylie, S. J., and Jones, M. G. K. 2011b. Characterisation and quantitation of mutant and wild-type genomes of Hardenbergia mosaic virus isolates coinfecting a wild plant of Hardenbergia comptoniana. Arch. Virol. 156: 1251-1255.

Wylie, S. J., Li, H., Dixon, K. W., Richards, H., and Jones, M. G. K. 2013 a. Exotic and indigenous viruses infect wild populations and captive collections of temperate terrestrial orchids (Diuris species) in Australia. Virus Res. 171:22-32.

Wylie, S. J., Li, H., and Jones, M. G. K. 2013b. Donkey orchid symptomless virus: A viral 'platypus' from Australian terrestrial orchids. PLoS One 8: e79587.

Wylie, S. J., Li, H., and Jones, M. G. K. 2014a. Yellow tailflower mild mottle virus: A new tobamovirus described from Anthocercis littorea (Solanaceae) in Western Australia. Arch. Virol. 159:791-795.

Wylie, S. J., Li, H., Saqib, M., and Jones, M. G. K. 2014b. The global trade in fresh produce and the vagility of plant viruses: A case study in garlic. PLoS One 9:e10544.

Wylie, S. J., Li, H., Sivasithamparam, K., and Jones, M. G. K. 2014c. Complete genome analysis of three isolates of narcissus late season yellows virus and two of narcissus yellow stripe virus: Three species or one? Arch. Virol. 159:1521-1525

Wylie, S. J., Luo, H., Li, H., and Jones, M. G. K. 2012a. Multiple polyadenylated RNA viruses detected in pooled cultivated and wild plant samples. Arch. Virol. 157:271-284.

Wylie, S. J., Tan, A. J. Y., Li, H., Dixon, K. W., and Jones, M. G. K. 2012 b. Caladenia virus A, an unusual new member of the family Potyviridae from terrestrial orchids in Western Australia. Arch. Virol. 157:2447-2452.

Zhang, T., Breitbart, M., Lee, W. H., Rn, J.-Q., Wei, C. L., Soh, S. W. L., Hibberd, M. L., Liu, E. T., Rohwer, F., and Ruan, Y. 2006. RNA viral community in human feces: Prevalence of plant pathogenic viruses. PLoS Biol. 4e3:1-8.

Zhang, Y., Singh, K., Kaur, R., and Qui, W. 2011. Association of a novel DNA virus with the grapevine vein-clearing and vine decline syndrome. Phytopathology 101:1081-1090. 